\title{
The Malay's traditional sweet, dodol: a review of the Malaysia's heritage delicacy alongside with the rendition of neighbouring countries
}

Norsyahidah Ismail ${ }^{1}$, Muhammad Shahrim Ab. Karim ${ }^{1 *}$ D, Farah Adibah Che Ishak', Mohd Mursyid Arsyad², Supatra Karnjamapratum ${ }^{3}$ and Jiraporn Sirison ${ }^{3}$

\begin{abstract}
The Malaysia's cultural heritage is authentic, unique and colourful with various local cuisines of different races and cultures. It is mainly originated from the Malay culture being the largest ethnic group in the country. The Malays themselves have contributed to many local cuisines ranging from appetiser, soup, main course and dessert. However, some Malay heritage foods have almost been forgotten and jeopardized in quality. This is especially happening to the Malay sweets or desserts which have gradually become less appealing to the younger generations. They are not even familiar with Malay foods, let alone consuming them. Among the popular Malay heritage foods in Malaysia are lemang, ketupat, rendang, wajik and dodol. Dodol specifically has been listed as one of the endangered heritage foods in Malaysia. Preserving the Malay cuisines is part of sustaining the Malay culture and this should begin with a great amount of knowledge and understanding about any elements within the culture itself. This article highlights a nostalgic and evergreen Malay's traditional sweet, known by the locals as dodol by discussing its history, different types and names of dodol, as well as the recipes, preparation, cooking methods and packaging. Furthermore, this article hopes to aid the readers, especially among the younger generations in the Malay community to have greater understanding and appreciation about their own beautiful culture.
\end{abstract}

Keywords: Dodol, Delicacy, Traditional, Heritage, Traditional food and ethnic food

\section{Introduction}

Malaysia is homed to various races and ethnic groups like the Malay, Chinese, Indian, Eurasian, Orang Asli and other local tribes and ethnicities in the Peninsular and East Malaysia like Iban, Dayak, Bidayuh, KadazanDusun, among others. The country is a melting pot of cultures for people of different backgrounds, ethnicities, beliefs, cultures, foods and many more. In 2020, Malaysia was reported to have 29.7 million populations with the Malays as the majority (69.9\%), followed by

\footnotetext{
* Correspondence: shahrim@upm.edu.my

${ }^{1}$ Department of Food Service and Management, Faculty of Food Science and Technology, University Putra Malaysia (UPM), Serdang, Malaysia Full list of author information is available at the end of the article
}

Chinese (22.6\%), Indians (6.8\%) and other ethnic groups (1\%) [1]. These ethnics amalgamate harmonious life which then advent an abundance of cultural and heritage sharing, exchanging and assimilation (Fig. 1).

The Malay in Malaysia is the biggest ethnic group and the people mainly originated from the Malay Archipelago. The Malays are rich in their cultural values, and this is evident based on their daily lifestyle. In the early days, some of the main activities of the Malays are farming and fishing. Their food diet mainly consists of rice and fish across different regions in Malaysia [2, 3]. Various end products can be derived from rice, for example glutinous rice in traditional desserts like tapai, dodol, kuih seri muka, kuih lapis, kuih lompang, kuih tepung pelita,

(c) The Author(s). 2021 Open Access This article is licensed under a Creative Commons Attribution 4.0 International License, which permits use, sharing, adaptation, distribution and reproduction in any medium or format, as long as you give

appropriate credit to the original author(s) and the source, provide a link to the Creative Commons licence, and indicate if changes were made. The images or other third party material in this article are included in the article's Creative Commons licence, unless indicated otherwise in a credit line to the material. If material is not included in the article's Creative Commons licence and your intended use is not permitted by statutory regulation or exceeds the permitted use, you will need to obtain permission directly from the copyright holder. To view a copy of this licence, visit http://creativecommons.org/licenses/by/4.0/. 


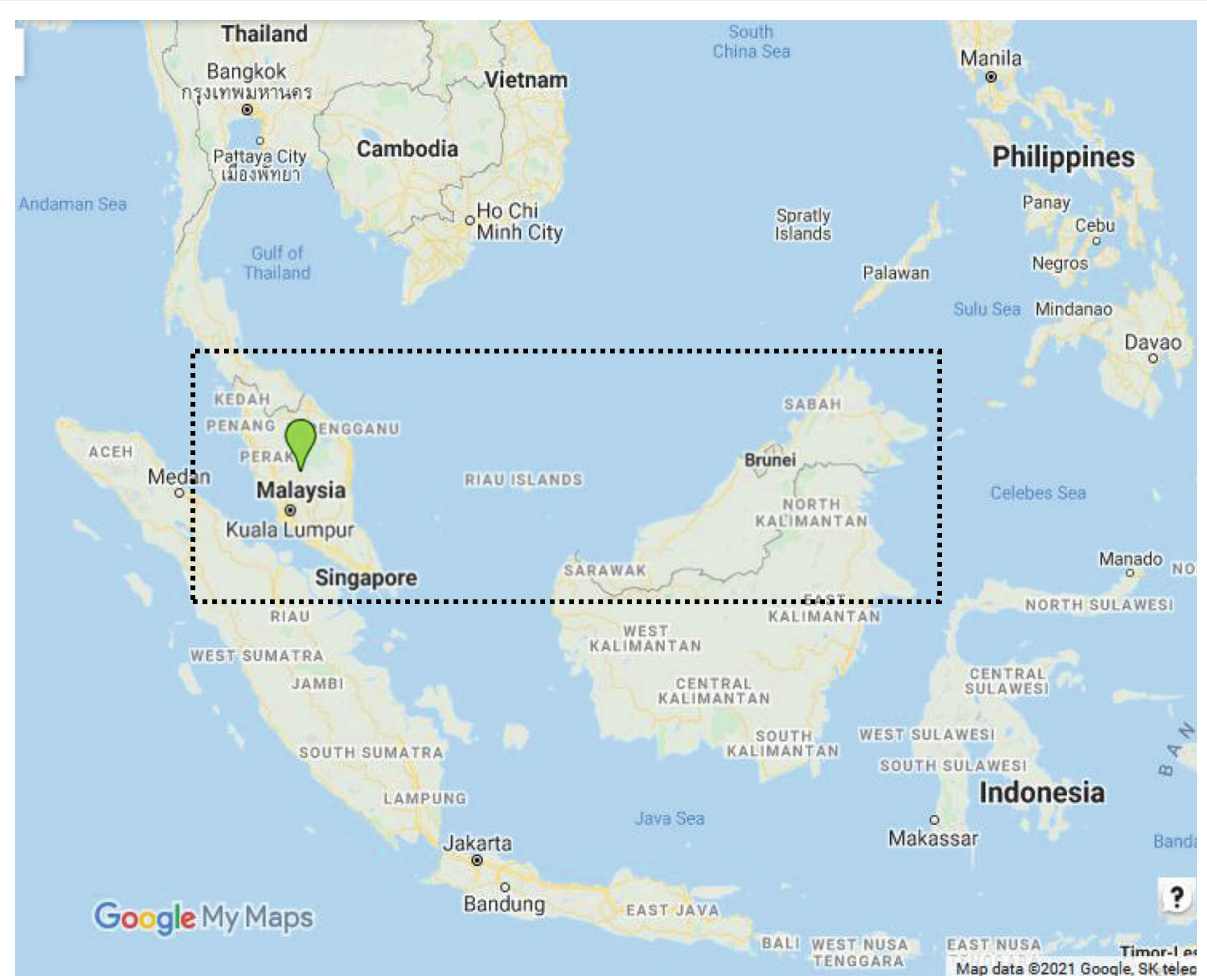

Fig. 1 Southeast ASEAN Map, location of study area, Malaysia

onde-onde and kuih koci [2]. The variation of Malay traditional desserts is a proof of the richness of the Malay culture and its food heritage [2]. Nevertheless, very little attention has been given to the role of traditional Malay kuih or dessert in a wider cultural lens $[2,4]$. For the purpose of this research, dodol was chosen to be reviewed as it is one of the most popular Malay traditional desserts that is currently listed as an endangered food by the Department of Malaysian National Heritage.

Literature related to dodol were previously analysed and it was found there is a gap in terms of dodol's scientific preparation to ensure its ability to be preserved longer. This article highlights the history and different types of dodol, recipes, preparation, cooking method and packaging. Finally, the significance of dodol during popular festivals in Malaysia is also discussed.

\section{Research method}

Popular academic databases such as Science Direct and Google Scholar were used in the search of quality references including scientific documents, published and unpublished works, reports, conference proceedings and books. The keywords used were "dodol" and "Malaysia". However, Science Direct covers a limited number of articles about dodol and it mainly discusses the scientific and clinical perspectives of dodol. In this case, Google Scholar database was mainly preferred because of its high accessibility to social science and humanities fields. Secondary literature about dodol also refer to books, local newspapers and websites available from 1954 to 2021 using English, Malay, Indonesian and Thai languages. Overall, writings that specifically focus on dodol, its history, recipes, preparation and cooking methods were chosen instead of writings that focus on dodol's different ingredients because these are beyond the scope of this article.

Dodol is the subject examined in this study. A popular Malay traditional dessert, it is also currently listed as one of the endangered foods by the Department of Malaysian National Heritage.

\section{Malaysian traditional food and Kuih}

The term traditional food has been widely used around the world and has various interpretations depending on the geographic regions [5]. Every traditional food has a unique background and history. It usually involves special preparation methods originally developed by a group of people sharing similar cultural practices and lifestyle within a particular region [5]. According to [6], the nature of a traditional food depends on the diversity of a country's culture. Certain traditional characteristics are found within the food itself. This particular definition is closely related to traditional foods that have specific cultural identity, historical period and heritage including the authenticity and the unique identity of certain places. 
Traditional food is typically prepared using ingredients that are easily accessible from the surrounding area [7]. For example, early settlers in Europe and America used to cook using natural resources available within their environment [8]. Traditional foods represent the cultural values or the identity of certain countries across the world. In Europe, the term "traditional" is linked with both food and traditions which have been practised in the community over time, demonstrating the heritage transmission between one generation to the next [9].

Heritage food is defined as a product which uses specific raw ingredients, methods, processes, techniques, materials and utensils in which the recipes have been passed down from older generation to the next generation [10]. Traditional food, on the other hand, refers to a special food that embodies the culture and ethnicity of a specific region [5]. The Malay ethnic in Malaysia for example is blessed with abundance of traditional foods [11] and among the popular ones are nasi lemak, nasi ayam, laksa and different types of kuih [2] which is the traditional Malay cake or dessert. Various kuih are typically served during teatime and occasionally during festivals, special events and throughout the day, including breakfast and afternoon snack. Generally, kuih can be categorised into two types, savoury and sweet [11]. Meanwhile, [12] discussed that the Malay kuih are distinctive in taste, texture and appearance. Most Malay kuih are chewy, creamy and sweet in which the typical ingredients are sweet potato flour, tapioca flour, coconut milk, shredded coconut, banana, palm sugar, sago palm and glutinous rice. They are either fried, grilled, steamed or baked [11] and can easily be found at the night market, roadside stall, café and restaurant.

Traditional kuih also symbolises the Malay identity and represents its history, lifestyle and heritage [10]. Some of the popular traditional kuih in Malaysia are bahulu, tapai and dodol, to name a few. For instance, bahulu is a Malay-style traditional sponge cake that is typically served during Eid, i.e. Hari Raya Aidilfitri and Hari Raya Aidiladha. Two of its popular types, bahulu cermai, have a button-like shape while bahulu ikan resembles the shape of a fish. Bahulu is traditionally baked on charcoal fire using specific mould. On the other hand, although dodol is a Malay dessert, all Malaysians regardless of their backgrounds have grown accustomed and enjoyed dodol too.

\section{Dodol in Asia region}

Dodol is a sweet that has a chewy, caramel-like and sticky texture which is made from glutinous rice flour, palm sugar and coconut milk [13]. Past scholars contended that dodol's earliest record was traced since 1926 in Betawi, Indonesia during Dutch colonial era [14]. The significance of using rice as one of the ingredients for dodol plays a huge role in symbolising the agrarian culture of Betawi people [15]. Another notable point is that the term "Betawi" was originated from the word "Batavia", a Dutch word referring to the Ancient Java [16]. Dodol was accessible only for the rich during that era [14] and the word dodol is as a confectionary which bears the meaning of sweet or sweetness [17]. In Thailand, some scholars asserted that this term was originated from the word "kelamai" or "gelamai" in Malay [18]. Similarly, in Malaysia, dodol is known as a sweet produced from glutinous rice flour, sugar and coconut milk [19]. Dodol is known as a type of sweetmeat that typically uses the same ingredients although it has many different names in various locales [20].

Dodol is also famous in Singapore, Thailand, Brunei, Philippines (Ilocos Region in Luzon and Lanao, Mindanao), Sri Lanka, India (Goa) and Myanmar. Interestingly, dodol is called differently across these countries, for example mont kalama in Myanmar and kalamea in Thailand. In India and East Africa, dodol is known as halwa [14] while in Central Java and East Java, it is known as jenang [21].

In Malaysia, dodol has always been a popular traditional dessert. The people in two states located at the upper southern region of Malaysia, Negeri Sembilan and Melaka, refer dodol as penganan [11] and kelamai, respectively. Dodol is also synonymous and close to the Malay culture. Malay is a type of race referring to a group of people originating from Sumatera. The interaction between the Westerners and Arabs with the Malay World started with their trading activities in the Indian Ocean involving the exchange of goods especially spices and forest products [22-24]. Over time, with the formation of Malaya (now known as Malaysia), prominent theories argued that the Malays who migrated from the southern Asian continent to the Peninsular and Borneo Island [25] brought along their goods and cultures in the migration process.

The Malay Archipelago refers to the archipelago between mainland Indochina and Australia. In the past, it was also known as the Malay World, Nusantara, Kunlun, Suyarnabhumi (Gold land), Yavadvipa (Gold Island or Golden Khersonase), Tanah Jawi and Melayu Raya [26]. Malay Archipelago covers the areas of Southern Thailand, Malay Peninsula, Java, Madura, Sunda, Borneo, Sulawesi, Philippine, the islands of Eastern Indonesia, including small parts in Cambodia and Vietnam [27, 28] To date, the Malay community can also be widely found in Indonesia, Thailand, Singapore and the Philippines. Therefore, it is not surprising that dodol can be discovered in these places.

\section{Types of dodol}

Information about dodol can be found in Indonesia, Thailand and Malaysia. According to [29], Indonesian 
dodol is made of coconut milk, glutinous rice flour, granulated sugar, brown sugar and salt, alongside the addition of unique ingredients in the final stage of preparation that give different taste to the dodol. They are known by different names owing to the origin or additional ingredients. For instance, dodol that is made from the flesh of durian is called dodol durian while dodol that is made from soursop pulp is called dodol sirsak and dodol that is made from jackfruit pulp is called dodol nangka. Other examples like dodol garut (Garut is a district in Indonesia), dodol kacang hijau (mung bean), dodol ubi talam (yam), dodol tomato (tomato), dodol apel malang (apple), dodol salak (thorny palm), dodol mangga (mango) and dodol lidah buaya (aloe vera) [21].

Other types of dodol in Indonesia are jenang, kadodo wera, betawi, kandangan and wajik which originated from South Sumatra. Dodol betawi is from Jakarta with brown sugar as its main ingredient while dodol garut is from West Java with rice flour as its main ingredient. In contrast, glutinous rice is the main ingredient in dodol kadodo wera and dodol jenang. Although both use the same main ingredient, kadodo wera is originally from Nusa Tenggara Barat while jenang is originally from East Java. Next, dodol kandangan is popular in Kalimantan and black glutinous rice is its main ingredient. Next, wajik is from Central Java with coconut as its main ingredient [21].

On the other hand, in Thailand, the ingredients and methods used to make kalamea are similar to those of the Malaysian version of dodol. Thai's kalamea can be classified into rice grain and rice flour kalameas. Rice grain kalamea or kalamea med is known for its traditional procedure alongside the long process of preparation. In contrast, the process of making rice flour kalamea or kalamea pang requires a distinctively shorter time than that of kalamea med. Therefore, kalamea pang has undergone mass production in Thailand as it is more economical compared to kalamea med [18, 30]. The original Thai's kalamea was invented by the Mon, migrants who lived in scattered settlements across Bangkok $[18,30]$.

Similarly, the Malaysian version of dodol also exists in many flavour variations. A lot of recent versions of dodol are inspired by innovative ideas which result in the interesting variations of colours, texture and taste. The most popular variations of dodol in Malaysia are made from durian, coconut and banana. Dodol durian is mouthwatering and has a lingering taste [31] which will satisfy durian lovers to enjoy durian in all its glory. Similar to the Indonesian version, dodol durian are made using glutinous rice flour, durian flesh, coconut and sweetening ingredients like brown sugar. It should also be noted that upih, which is the dried leaf of the betel tree is used as the traditional packaging of dodol.
Several states in Malaysia such as Melaka, Perak, Negeri Sembilan and Johor are dodol's main producers. Melaka is famous for a few variations of dodol such as dodol kelapa (coconut), dodol pisang (banana), dodol mangga (mango), dodol nanas (pineapple), dodol pandan (screw pine) and dodol kopi (coffee). Dodol mangga, and dodol asli are more popular in Johor. Meanwhile, in Negeri Sembilan, a few notable variations of this sweet are dodol asli and dodol pilah. Dodol pilah is made using gula enau or commonly known as the palm sugar. The name of this sweet is attributed to the place of origin of this sweet which is Kuala Pilah, one of the districts in the state of Negeri Sembilan. As for the state of Perak, some of the famous dodol include dodol pulut hitam (black glutinous rice) and dodol asli (original). In contrast, wajik sirat can be more easily found in East Malaysia and it is made from glutinous rice instead of flour [31-34].

Dodol is also famous in some regions across Asia, especially during festive celebrations like Christmas in Goa, India [34], Songkran festival, Buddhist priesthood and merit ceremonies in Thailand [30] and Hari Raya in Malaysia, Indonesia and the Philippines [20,34, 35].

\section{Basic ingredients of dodol}

The basic ingredients for dodol can be found easily in Malaysia. For example, in the past, glutinous rice was planted and harvested before it went through the grinding, pounding and sieving processes to produce glutinous rice flour. In addition to this, palm sugar is also used as one of the main ingredients to make kuih in Malaysia. This type of hardened syrup derived from sugar palm tree (Arenga pinnata) called gula Melaka or gula kabung has been used in the Malay traditional sweets since the olden days [2]. Gula Melaka is made by boiling the liquid collected from the cut stem of immature palm inflorescences or flower stalks of the coconut palm. Certain processes need to be carried out to make palm sugar for cooking purpose. It needs to be cooked until the liquid is reduced and finally poured into various moulds [36]. Apart from this, another famous ingredient that can be found in Malay cooking is coconut milk. In Malaysia, coconut trees are usually planted within the compound of traditional Malay houses. In the olden days, the Malay people used to collect the coconuts nearby their houses for cooking purpose. The economic activities of the Malay people in the past such as planting rice, collecting the sugar palm syrup and coconut have greatly impact the food culture of the community and have influenced the choice of ingredients to cook dodol.

One of the common ingredients for dodol is coconut milk which is the liquid extracted from the grated meat of a matured coconut. Other ingredients include 
glutinous rice flour, granulated sugar, brown sugar or palm sugar, salt and pandan or screw pine leaves (additional). Similar dodol ingredients are also available in other countries like Indonesia, Thailand, India, Myanmar and the Philippines.

\section{Basic dodol recipes}

Glutinous rice flour, coconut milk and palm sugar are the main ingredients in cooking dodol but different recipes call for different portion or ratio for each of the ingredients. However, the aim is the same which is to produce dodol of gooey, creamy texture with coconutty flavour and sweet taste. It is typically a family recipe which remains a secret and specialty for business purposes. The following is the examples of normal ratio for dodol in Thailand and Malaysia.

Thailand dodol recipe

\begin{tabular}{ll}
\hline Glutinous rice flour & $2 \mathrm{~kg}$ \\
Coconut milk cream & $5 \mathrm{~kg}$ \\
Palm sugar & $3 \mathrm{~kg}$ \\
Roasted white sesame & for coating \\
\hline
\end{tabular}

Malaysia dodol recipe

\begin{tabular}{ll}
\hline Glutinous rice flour & $1.5 \mathrm{~kg}$ \\
Coconut milk cream & $6 \mathrm{~kg}$ \\
Palm sugar & $6 \mathrm{~kg}$ \\
Plain water & $2 \mathrm{~L}$ \\
\hline
\end{tabular}

As can be seen, similar ingredients are used, namely glutinous rice flour, coconut milk and palm sugar but with different portion or ratio. In the Thai recipe, roasted white sesame is added for coating after the cooking process which contributes to special aroma and appearance [30]. Meanwhile, in Malaysia, plain water is added to the palm sugar to produce palm sugar syrup beforehand. In addition, there are many versions of recipes in Malaysia with similar cooking steps. For example, the palm sugar can be chopped or melted following the recipes inherited from the earlier generations. The step of adding water is individual-based preference.

\section{Method of cooking}

Making dodol requires meticulous and rigorous methods; approximately six to eight hours to cook this dessert [29, 37]. Furthermore, the cooking process needs a special skill in controlling the heat and manual mixing technique of dodol which is cooked using a huge wok. Dodol is traditionally cooked using wood-burning stoves that will produce a special smoky aroma that creates a nostalgic and distinct flavour of dodol.

\section{Cooking process \\ Traditional way of cooking dodol}

The making of traditional dodol requires a lot of time, energy and fresh ingredients. It also requires meticulous effort, skill and proper technique to produce the right texture and flavour of the dodol. The cooking process of Thai dodol starts with the preparation of the right amount of ingredients such as glutinous rice flour, coconut milk, palm sugar, sesame seed as garnishing and proper utensils such as a large wok and steel stirrers using firewood to cook. The process of making dodol in Thailand is illustrated in Fig. 2(1-10).

A traditional dodol is typically cooked in a large volume with more than one person to do the job. This demonstrates the values of unity and teamwork as part of an important cultural quality. Cooking dodol in Malaysia involves several labour-intensive, traditional methods using fresh and natural ingredients over the firewood or charcoal [38]. It is common for older generations to take lead in making dodol and monitor the cooking process as they are more experienced in this. The traditional method can also be quite exhausting as it mainly requires manual labour from start to finish including collecting the firewood, mixing the ingredients and stirring the loose liquid mixture incessantly until it becomes chewy, sticky and dark brown in colour. The image in Fig. 3 shows one of the stages involved in making dodol.

As previously described, the utensils and the necessary ingredients need to be prepared earlier before the cooking process begins. The process of making dodol is illustrated in Figs. 4, 5 and 6.

While in the wok, it needs to be constantly stirred on medium heat until it becomes smooth and slightly thicker in texture.

\section{Modern way of cooking dodol}

The modern method of making dodol is slightly different compared to the traditional method in which manual labour is replaced with automated equipment. The usage of modern technology applied in the process of making dodol clearly alters the preparation time, energy level, cooking technique and aroma [39]. The modern technique utilizes the convenience of machines to continuously stir the dodol mixture throughout the cooking process. Figure 7 shows dodol produced by an automated machine using electric power or gas can produce better quality of dodol [39].

Next, it can be observed that the appearance and colour of the modern dodol are almost similar to ones cooked using traditional method. However, a slight 


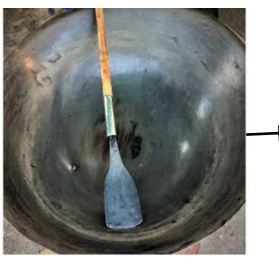

2.1

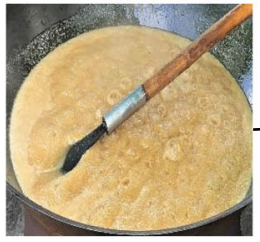

2.5

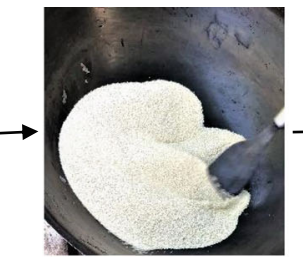

2.2

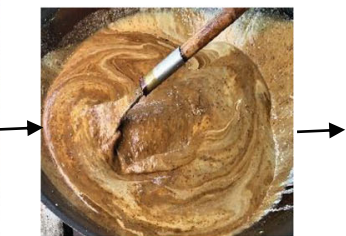

2.6

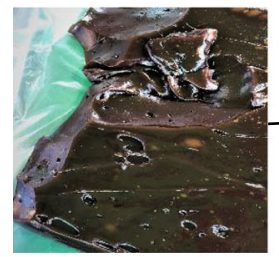

2.9

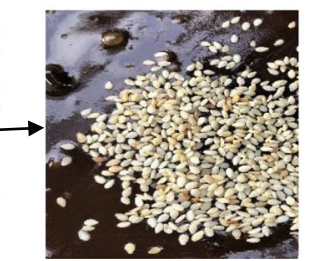

2.10

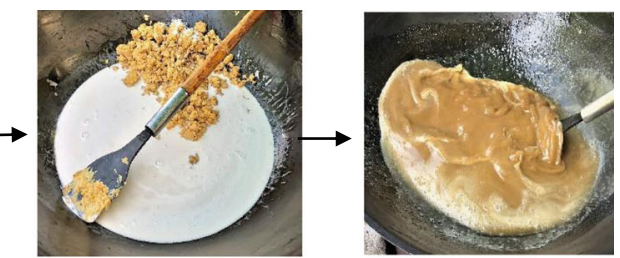

2.3

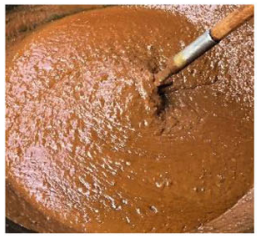

2.7
2.4

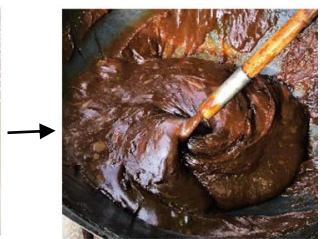

2.8

Fig. 2 (1-10) The traditional process of making kalamea in Thailand

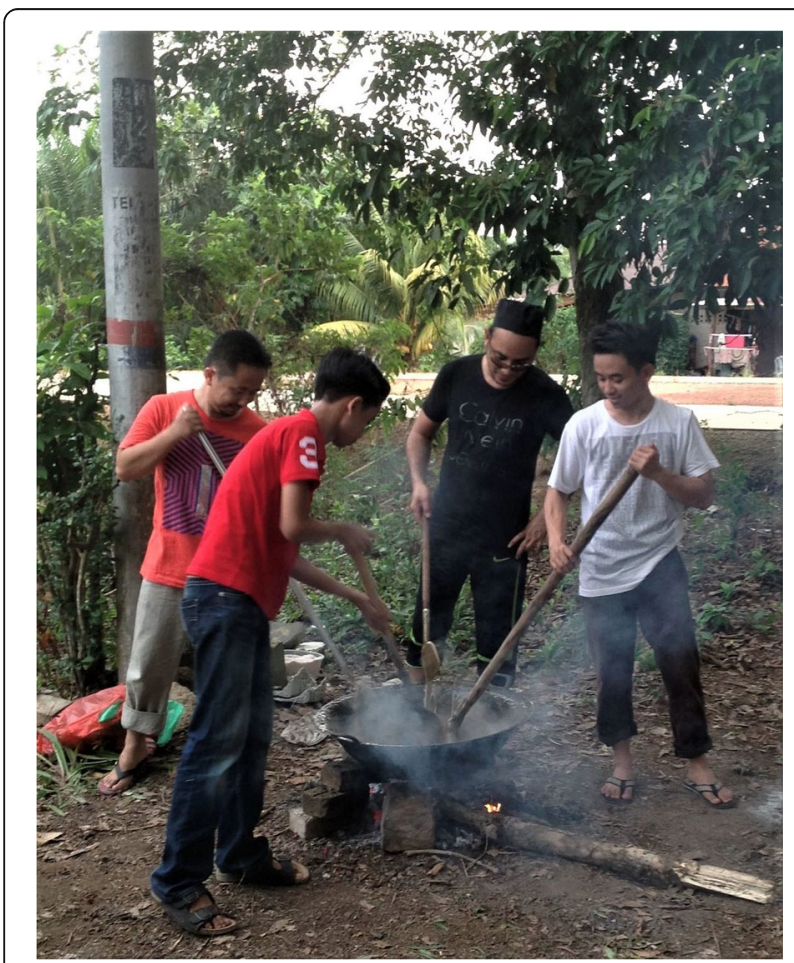

Fig. 3 The traditional method of cooking dodol using manual labour, usage of firewood and traditional cooking utensils

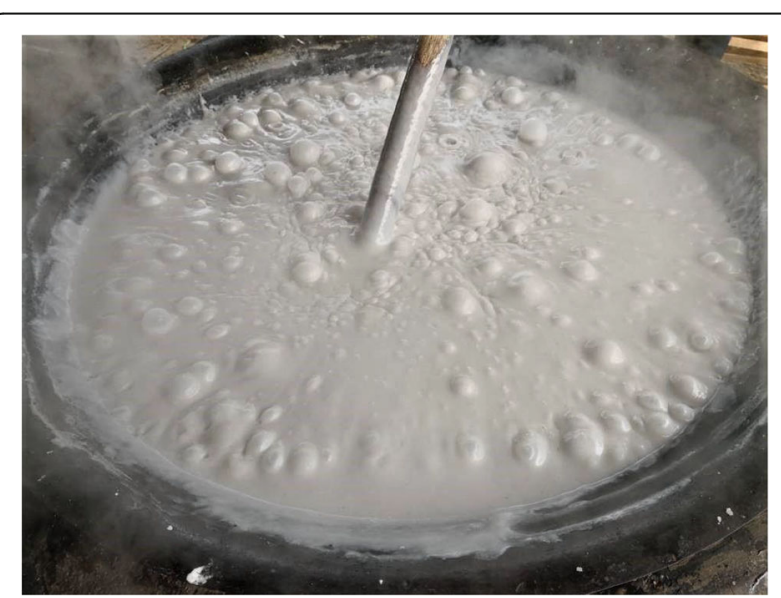

Fig. 4 Glutinous rice flour and coconut milk are mixed together and the mixture is then strained into the wok to get smoother mixture 


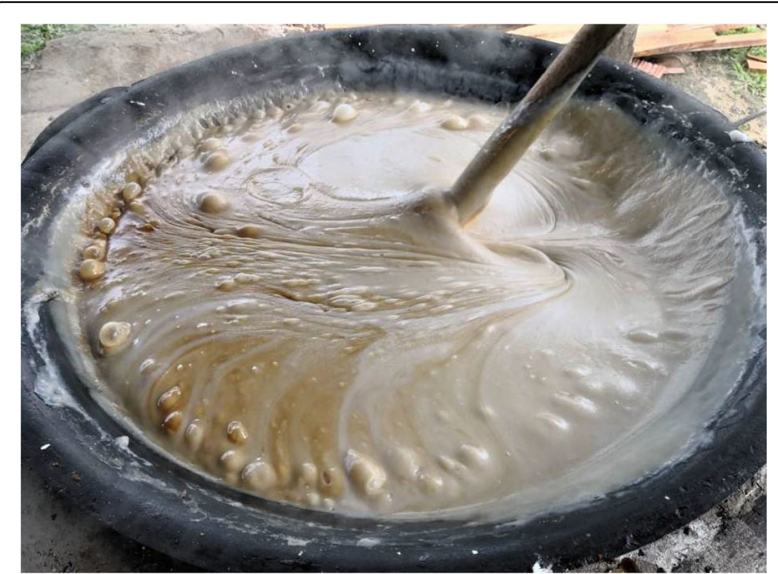

Fig. 5 Chopped brown sugar is added into the mixture and the mixture must continuously be stirred until the sugar is completely melted and blended into the mixture

difference between the traditionally cooked dodol and the modern ones can still be detected in terms of their taste and texture. The traditional dodol is softer and more delicate than dodol that is produced using a machine [13]. The use of machine affects the taste and texture of dodol especially when the temperature gradually increases over time $[40,41]$.

The traditional and modern dodol are equally popular in Malaysia due to their availability in the market. Notably, using either dodol machine or manual stirring are time consuming. The difference between traditional and modern dodol is mainly based on the technique to cook dodol and how the dodol is stored or packed. Although similar ingredients, namely glutinous rice flour, coconut milk and palm sugar are used in both traditional and modern dodol, the tastes are significantly different in the sense that traditional dodol has special aroma and smoky taste coming from the usage of

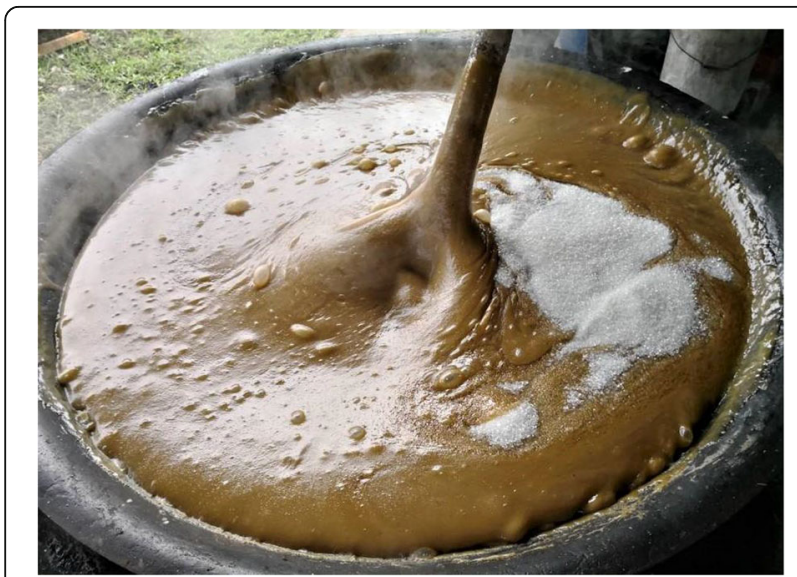

Fig. 6 The stirring continues until the mixture becomes really thick and sticky. The colour of the mixture will turn dark brown as it is cooked longer

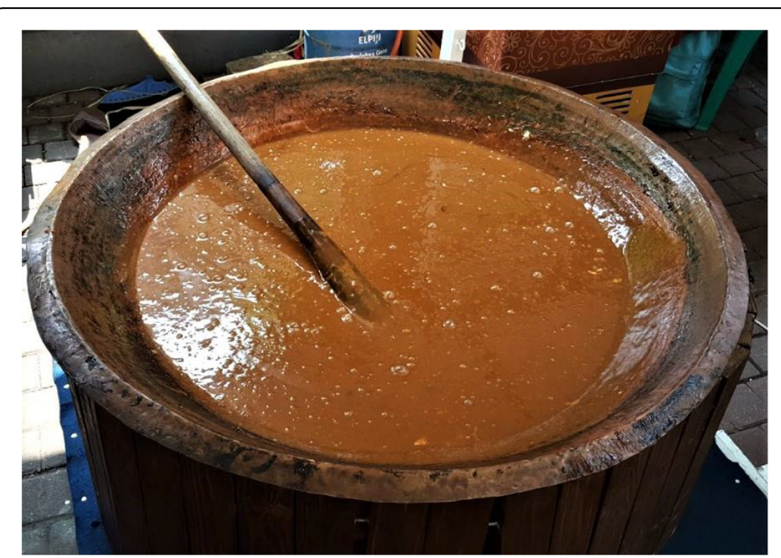

Fig. 7 Cooking dodol using gas stove can produce better quality of dodol

firewood or charcoal [38]. The traditional dodol is also labour-intensive, hence the texture is a lot smoother and delicate [40] due to a prolonged, personalized stirring process. Meanwhile, modern dodol replaces labour force with automated stirring machine and gas stove. This way is energy-safe and creates a smoke-free environment. The colour is similar to that of traditional dodol but at the expense of the special smoky taste and delicate texture [20]. Other than that, traditional dodol in the past requires a manual practice of grinding the glutinous rice flour, as well as the process of shredding and squeezing the coconut to produce the coconut milk. Currently, the manual process is replaced with advanced technology and automated machines. In Malaysia, the application of technology used in producing dodol is seeing an upward trend. Dodol is produced in bulk quantity and imported to many countries such as Singapore, Brunei and China [39].

\section{The variations of packaging dodol Traditional packaging}

The evolution of food packaging can be clearly observed over time. Initially, different types of leaves would be used by the earlier generation as the traditional way of food packaging. It is also recorded that this traditional method of food storage and preservation has been practised by the people in Southeast Asia since the last five decades [42]. Traditional food packaging is mainly for food protection and includes natural materials such as various types of leaves, bamboo, rice straw, paper and hemp twine [4]. Leaf is a popular source of packaging material as it is cheap, available at any time and can prolong the food storage. Thai kalamea, and Malaysian dodol are wrapped nicely following the traditional process. Practically, the food is wrapped in banana leaf, leaf sheath of betel palm, or coconut sheath. As 
explained by [42], the common types of trees and leaves used to wrap and act as packaging for the traditional foods are planted nearby the housing area throughout Malaysia can easily be bought at the local markets. To date, the traditional method of packaging is still widely used in foodservice, display, preparation and sales for cottage industries.

Various types of leaves are also used as the traditional packaging of dodol. In addition, leaves are traditionally used as a common food packaging as to some extent, it can preserve the quality of the food for long journeys and travels. It has been further suggested that packaging by leaves can give an aromatic sense and taste to the food [43]. Some of the popular types of leaves used as food wrapping in Malaysia include coconut, banana, upih (betel-nut palm sheath) and palas leaves (also known as Licuala sapinosa Roxb or thorn Palas tree) since these materials can be easily found across Malaysia and the supplies are continuous throughout the year [42]. Figure 7 shows one of the examples of the traditional packaging using leaves (Figs. 8, 9 and 10).

\section{Modern packaging}

Modern packaging is currently a popular option, especially among food producers. Entrepreneurs prefer using packaging that is safe, hygienic and aesthetically pleasing [44]. It is vital for the traditional food industry

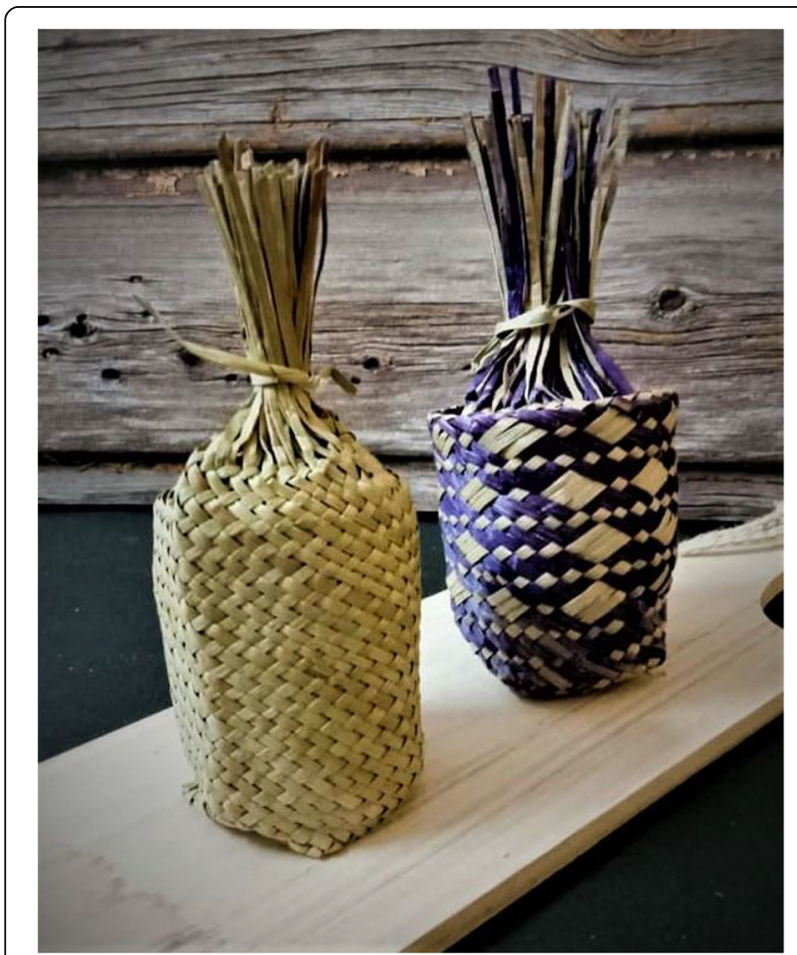

Fig. 8 One of the fancier traditional dodo/ packaging is called tampin; the Malays' handcrafted container made from woven dried mengkuang leaf

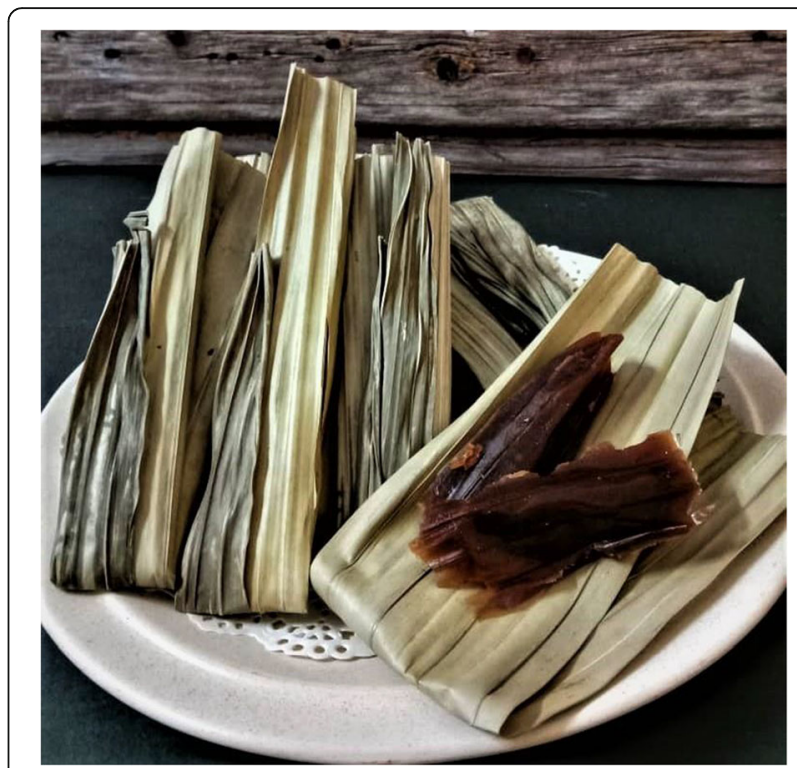

Fig. 9 Dodo/ wrapped in palas leaf

to keep innovating and improving the quality of food packaging including the packaging for dodol and at the same time maintaining its authentic taste and texture [45].

In the production of dodol, the main problems faced by many of the entrepreneurs are its short shelf-life and the change of texture during the storage process [20]. Studies discovered that packaging is one of the crucial factors that helps to maintain the quality of dodol [20, $29,45]$. The modern packaging helps to protect foods from various types of pollutants, as well as facilitates labelling work. Good hygiene practice must also be adhered to avoid food contamination [20]. Apart from

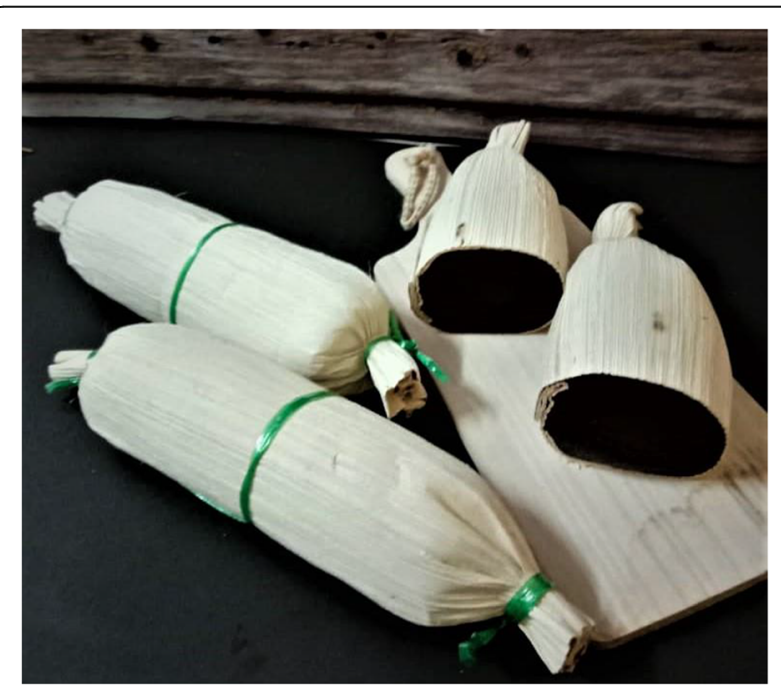

Fig. 10 Dodo/ wrapped in a dried upih (also known as areca nut leaf frod stems) 
serving as the protective material for dodol, packaging that employs numbering system is also useful for packing and transportation. Besides, a good-quality packaging boosted the product while convincing the customers that the product is the best choice among others $[20,45,46]$. In this section, the comparison of packaging types and sizes between Malaysia and Thailand is shown in Figs. 11, 12, 13, 14 and 15.

Zooming in to Thailand, kalamea has been produced with mixtures of different colours and flavours and they are packed in appealing plastic film. Pictures of various flavours of the Thai kalamea are shown as follows:

Meanwhile, dodol in Malaysia are packed in modern plastic packaging and boxes with various colours and sizes. The following images show various shapes and types of dodol packaging in Malaysia.

Packaging is an important factor to preserve the quality of dodol [20, 29]. The traditional method of packaging applied by earlier generations is still available until today although the quantity has decreased. For example, dodol wrapped in upih has a high demand during Hari Raya because of its quality aroma and taste [37]. However, it is not easy to find natural resources for packaging like upih, palas and mengkuang leaves due to the extinction and cheaper version of modern packaging. Currently in Malaysia, the modern packaging uses plastic container or wrap which is safer, attractive, informative [44] and easy to use [37]. It has the potential to fully replace the traditional packaging yet at the same time dodol may slowly lose its distinctive identity [47], special aroma and flavour $[48,49]$.

\section{The nostalgia of dodol making in the past in Malaysia} For the past few decades, dodol has typically been associated with festive seasons such as Hari Raya

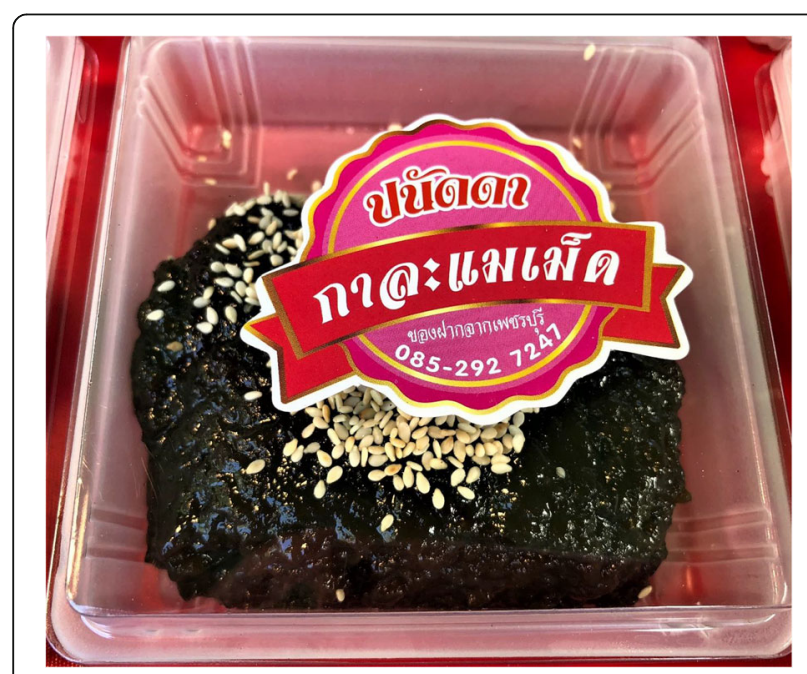

Fig. 11 Kalamea in Thailand

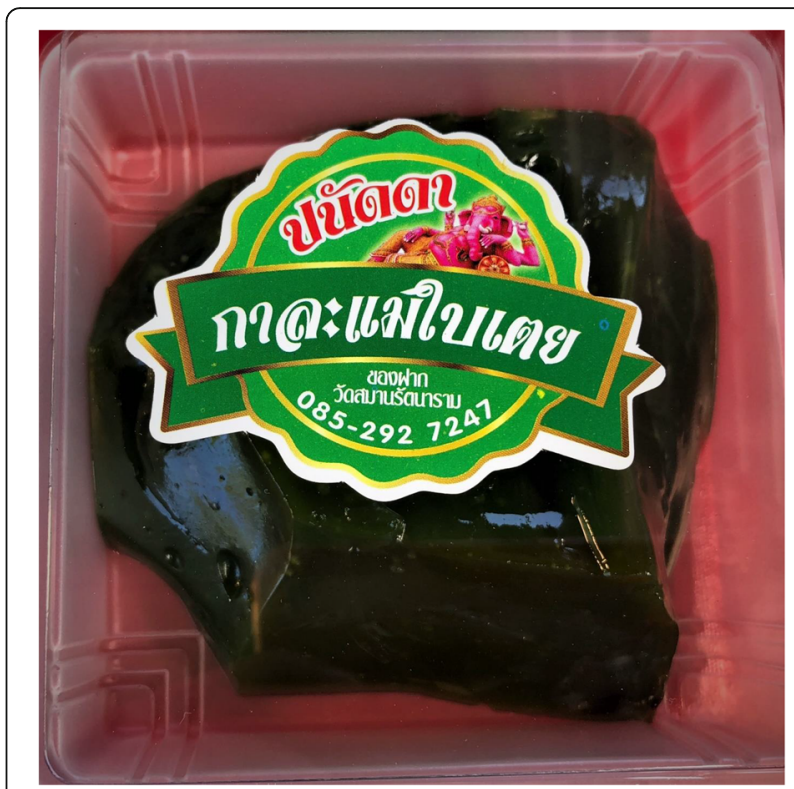

Fig. 12 Kalamea Pang: Pandan-leaf flavoured kalamea in Thailand

Aidilfitri or Hari Raya Aidiladha in Malaysia. Dodol is especially popular among the Malays, and it has become an essential dessert alongside other Malay festive foods such as the lemang (glutinous rice with coconut milk cooked in bamboo tubes), ketupat (a Malay traditional white rice cake) and rendang (a dish resembling stew but relatively dry; cooked in coconut milk with spices for several hours and can be kept for a long-term storage). This traditional confectionery is synonymous with Malay food culture and identity as it is usually prepared by the Malays during important occasions.

(a) Traditional Malay food during festive seasons

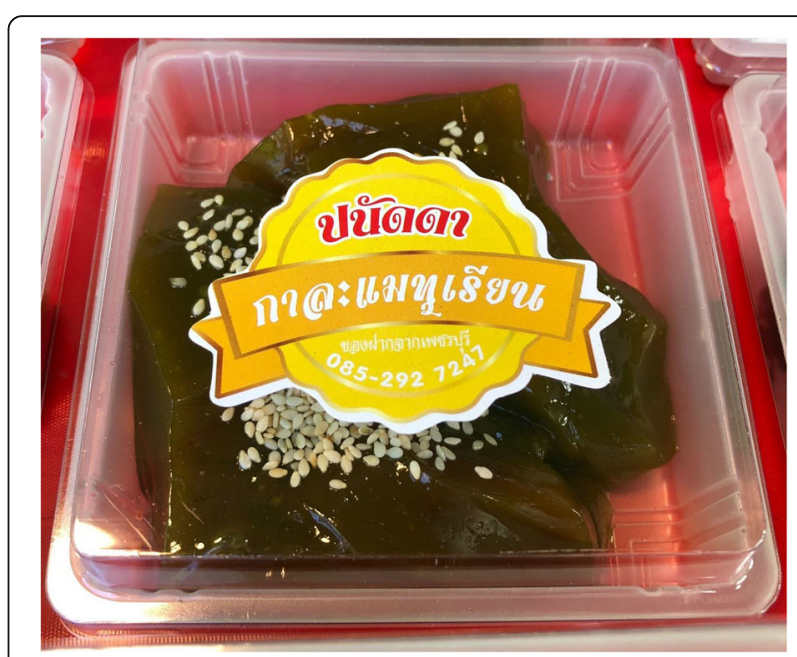

Fig. 13 Kalamea Pang: Durian-flavoured kalamea in Thailand 


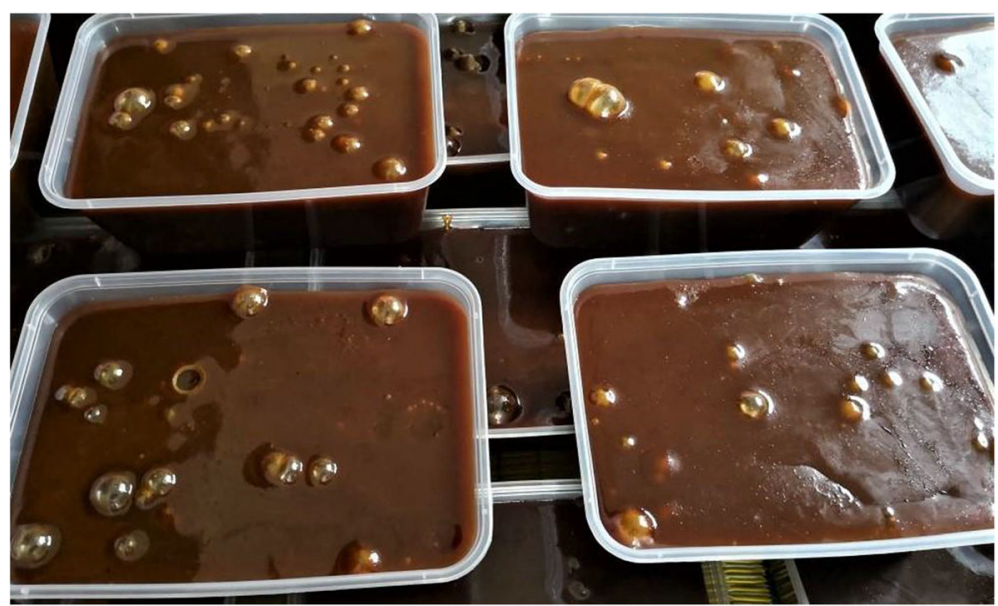

Fig. 14 Dodol packed in a rectangular plastic shape container

The Malays in Malaysia embrace the religion of Islam. They celebrate Hari Raya Aidilfitri and Hari Raya Aidiladha as their main religious festivals. Traditionally, the custom of travelling back to kampung or hometown is widely practised by the Malays to visit their relatives and friends during these festive seasons. Usually, the travellers would arrive at their hometown during the final week of Ramadhan (fasting month for Muslims) to celebrate Hari Raya Aidilfitri (the breaking fast festive celebrated by Muslims) in Syawal (the month following Ramadhan in the Muslim calendar). Malam Tujuh Likur

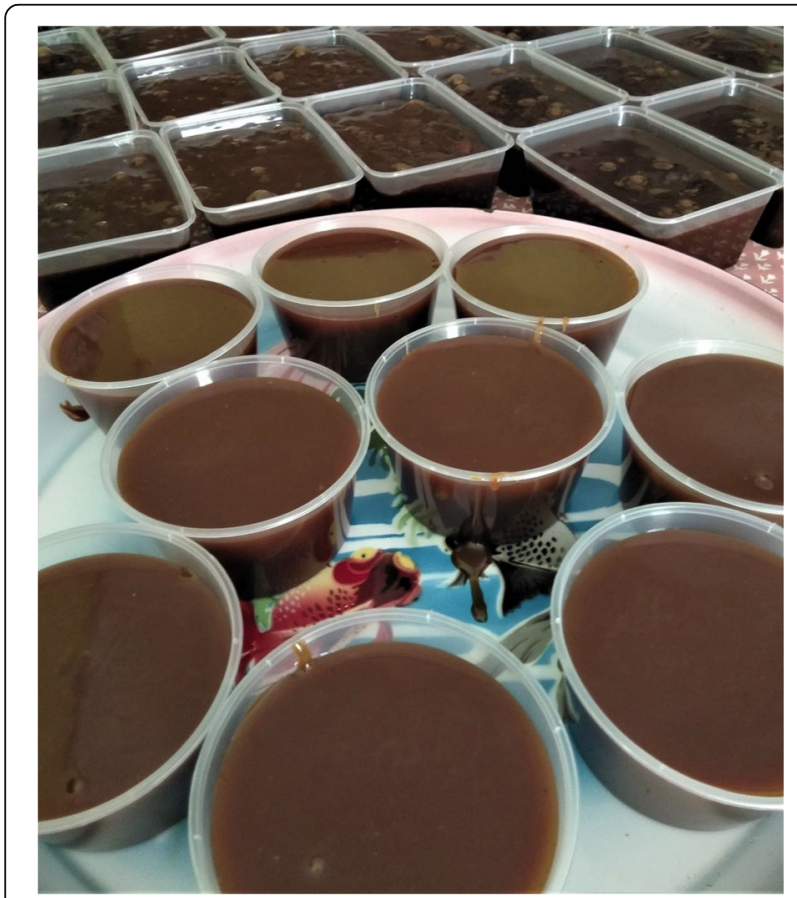

Fig. 15 Dodol packed in round-shape and rectangular plastic containers in Malaysia
( $27^{\text {th }}$ day of Ramadhan) is one of the traditional occasions where the oil lamps or pelita are fixed around the compound of their houses. Other activities include house cleaning and cooking preparation for the special festive dishes such as lemang (glutinous rice with coconut milk cooked in bamboo tubes), rendang (a dish resembling stew but relatively dry; cooked in coconut milk with spices for several hours; can be kept for a long-term storage) and ketupat (a Malay traditional dish made from white rice). During Hari Raya Aidilfitri, dodol is served among the popular main dishes like ketupat and rendang [11].

(b) Dodol making preparation for Hari Raya

The traditional methods of cooking dodol require a substantial amount of time and energy in which the process usually involves collaboration among family members or neighbours. Preparing the ingredients and cooking utensils like glutinous rice flour, coconut milk, brown sugar, salt and pandan leaves, as well as wok, wood stirrer and firewood stove is usually done 3 to 4 days prior to the cooking. In the olden days, the elders and children in the community join activities to collect coconuts and for the preparation of dodol; at least one week before the cooking process. Coconut husk is also gathered to be used for fire ignition. Scholars have proven that in the old days, the coconuts trees could be found within the vicinity of most of the Malay houses [50-52]; hence, it was easy for the people to collect coconuts and firewood that were available in their area. Old coconuts that are dry and brown in colour are collected during this process. People typically collect the fallen coconuts and place them in a dry place so that they can be used for cooking after the coconut turns brown. The brownish coconut must be removed from 
the coconut husk and shell so that the coconut milk can be obtained. As for the firewood, they must be collected earlier to ensure that they are in good and dry condition so that it could be an effective fuel for the firewood stove.

(c) Gotong-royong (community work) activities in dodol preparation

The gotong-royong activity usually begins early in the morning where the cooking will be done collectively with some people specialising in specific work at a time. When everyone is gathered at the venue where the cooking takes place, they are divided into task-based groups so that the preparation can occur simultaneously. Before igniting the flame, important ingredients such as the coconut milk and glutinous rice flour must be prepared. As mentioned in the earlier section, the ingredients for dodol are prepared before the cooking process starts. The gotong-royong activities usually starts with the grating of the coconut flesh or locally known as kukur kelapa to obtain the coconut milk. This part task is done by three or four people at a time. Subsequently, the grated coconut will be squeezed to get the extract of the coconut milk. Following this process, glutinous rice flour will be mixed with coconut milk, and it is vital to make sure that the glutinous flour is completely dissolved in the coconut milk [53]. Afterwards, the mixture of glutinous rice flour and coconut milk is filtered and placed in a pot. At this moment, two to three people are involved in this process and simultaneously, the men would prepare the cooking utensils and start making fire for the stove. The flame must also be ignited using coconut husk and firewood. Then, a stove and wok are placed in the middle of the fire. Following this step, the mixture of the filtered glutinous rice flour and coconut milk is poured into the wok, alongside the mixture of cooked brown sugar with pandan leaf. At this stage, this mixture must be stirred continuously until it turns thicker and harder. Notably, dodol needs long hours to cook and gotong-royong activity is important during the process of stirring dodol. During these long hours, a different group of people take turn to stir the dodol to ensure that it is well-cooked and does not stick to the wok to prevent it from scorching.

The most significant value in dodol-making tradition during the festive season in the Malay community is gotong-royong activities. Historically, the process of making dodol is labour-intensive, involving not only the family members who organise the preparation but also the neighbours. The whole process encompasses early preparation such as collecting coconuts and firewood, squeezing the coconut, igniting the fire, kneading the glutinous flour and stirring dodol mixture until it thickens. This culture highlights the fundamental elements of social ties by helping each other and working together so that difficult works become easier and smooth.

As a platform to strengthen the relationship among family members and neighbours, gotong-royong activities can act as an avenue for people to communicate and exchange news during Hari Raya celebration in their kampung or hometown. Evidently, the ritual of cooking dodol helps to enhance the spirit of goodwill, harmony and unity among the kampung community [52]. For example, the senior members of the community who participated in this event would share their stories, such as their past experiences as well as the joy and gratitude about the coming celebrations. This event would create many precious moments for the younger generations, and it is also significant to the nostalgia of making dodol and the cultural values associated with this traditional dessert. A similar study by [54] discovered that the tradition of gotong-royong in Malaysia is also practised during kenduri kahwin (matrimonial ceremonies). The people in the village or kampung will devote their personal time and energy to help the wedding host through this communal affair. However, more recently, the practice of gotong-royong is slowly diminishing in both urban and rural areas. Sadly, it has also affected the cooking process of cooking traditional dodol that requires gotong-royong activities due to the long cooking hours and complicated production.

\section{Conclusion}

In conclusion, dodol is a unique and popular heritage food in Malaysia which unfortunately has been listed as one of the endangered foods by the Malaysian Department of National Heritage. Therefore, it has to be preserved by any means using different traditional and scientific methods. First, the traditional preservation method should begin by documenting the traditional recipe of dodol passed down orally from the older generation to the younger generation. At the same time, scientific methods need to be adapted to ensure dodol survives the era of modernization which include educating the public about the history and different types, recipes, cooking methods, packaging, and ceremonies associated with traditional and modern dodol.

This article has featured dodol from the perspectives of the Malay culture in Malaysia. Other Asian countries like Indonesia, Thailand, Singapore, the Philippines, Myanmar and India also produce dodol-like dessert known with different names. History suggested that dodol was invented by the Malays, but it is not accurate to claim that this traditional dessert is unique to only the Malays in Malaysia. It is indeed true that dodol 
represents the Malay culture in different countries around the world and at present, dodol has undergone innovation process especially in terms of the taste, variation and technology.

Finally, dodol has significantly represented the Malay food culture by showing a strong social bond between different generations, family members, neighbours and the surrounding communities and hopefully this traditional dessert remains relevant despite the threat as one of the endangered heritage foods in Malaysia.

\section{Acknowledgements}

The authors would like to express their appreciation to Universiti Putra Malaysia for the opportunity and encouragement in pursuing the research on heritage and traditional food. The authors would also like to thank the selected dodol producers in Malaysia and Thailand for their cooperation during the photo session of dodol-cooking process.

\section{Authors' contributions}

All authors have contributed their ideas and in the overall construction of this manuscript. All authors reviewed and approved the final manuscript.

\section{Funding}

This research did not receive any specific grant from any public, commercial, or not-for-profit funding agencies.

\section{Availability of data and materials}

All data and materials are used in accordance of the guideline of the Journal of Ethnic Foods as listed in the reference section. Images are personally contributed by the authors.

\section{Declarations}

\section{Competing interests}

The authors declare that they have no competing interests.

\section{Author details}

${ }^{1}$ Department of Food Service and Management, Faculty of Food Science and Technology, University Putra Malaysia (UPM), Serdang, Malaysia. ${ }^{2}$ Department of Professional Development and Continuing Education, Faculty of Educational Studies, Universiti Putra Malaysia (UPM), Serdang, Malaysia. ${ }^{3}$ School of Food Industry, King Mongkut's Institute of Technology Ladkrabang, Ladkrabang, Bangkok 10520, Thailand.

\section{Received: 18 March 2021 Accepted: 2 August 2021}

\section{Published online: 17 August 2021}

\section{References}

1. Deparment of Statistics, Malaysia. Press release current population estimates, Malaysia (2019-2020). Malaysia: Department of Statistics, Malaysia; 2020.

2. Kamaruzaman MY, Ab Karim S, Che Ishak FA, Arshad MM. The diversity of traditional Malay kuih in Malaysia and its potentials. J Ethnic Foods. 2020; 7(22):1-11.

3. Laderman C. Food ideology and eating behavior: contribution from Malay studies. Soc Sci Med. 1984;19(5):547-59.

4. Mustafa M, Nagalingam S, Tye J, Shafii AS, Dolah J. Looking Back To The Past: Revival of Traditional Food Packaging. 2nd Regional Conference on Local Knowledge (KEARIFAN TEMPATAN). Jerejak Island, Penang: Universiti Sains Malaysia; 2012. p. 1-17.

5. Shin DH. Korean traditional food: status, prospects and vision for globalization. Food Fertilizer Technol Centre. 2010;557:1-13.

6. Albayrak M, Gunes E. Traditional foods: interaction between local and global foods in Turkey. Afr J Bus Manage. 2010:4(4):555-61.

7. Ivanova L, Terziyska I, Trifonova J. Characteristics of traditional food-the viewpoint of tourism business. J Serv Manage. 2014:3:123-30.

8. Pollock N. Diversification of foods and their values: pacific foodscapes. In: Tides of Innovation in Oceania; Value, Materiality and Place. Australia: ANU Press; 2017. p. 261-93.
9. Hamzah H, Ab. Karim MS, Othman M, Hamzah A. Dimensions of authenticity in Malay cuisine from experts' perspectives. Acad J Interdiscip Stud. 2013; 2(3):369-77.

10. Hamzah H, Ab. Karim MS, Othman M, Hamzah A, Muhammad NH. Challenges in sustaining the Malay traditional kuih among youth. Int I Soc Sci Humanity. 2015;5(5):472-8.

11. Raji MNA. Past and present practices of the Malay food heritage and culture in Malaysia. J Ethnic Foods. 2017:4:221-31.

12. Sharifah Azizah TN, Shafii NS, Haron H. Amounts and types of sugar in selected commercial and traditional kuih in Malaysia. Int Food Res J. 2015; 22(6):2642-9.

13. Seow E-K, Tan T-C, Mat Easa A. Role of honey diatase on textural, thermal, microstructural, chemical, and sensory properties of different dodols. J Food Sci Technol. 2021;148:8.

14. Z. Aziz, "Dari Mana Datangnya Dodol? Ini Dia Asal Usul Makanan Kegemaran Kita Yang Anda Perlu Tahu," 2017. Available: https://says.com/my/seismik/a sal-usul-dodol. Accessed 1st Mar 2018.

15. Sudiyanti T. (2016). Studi Deskriptif Tentang Perkembangan Usaha Dodol Picnic Garut. Universitas pendidikan Indonesia, Fakultas Pendidikan Ekonomi dan Bisnis. Bandung: Universitas Pendidikan Indonesia. 2016. Retrieved June 02, 2018, from https://123dok.com/document/yrwlj8jz-studi-deskriptif-tenta ng-perkembangan-usaha-dodol-garut-repository.html.

16. Shahab A. Betawi: Queen of the East. 1st ed. Jakarta: Republika; 2002.

17. Crawfurd J. Grammar and dictionary of the Malay language with a preliminary dissertation. London: Amith, Elder, and Co; 1892. p. 16

18. Khuamornphatana N. The route of Thai dessert: origin and evolution of Thai dessert from Sukhthai period. Bangkok: Sengdad; 2010. p. 191.

19. Dewan K. Kamus Dewan. 4th ed. Kuala Lumpur: Dewan Bahasa dan Pustaka; 1998

20. Zahid K, Wahid MA, Ahamad N, Moey SW, Ramli A, Sarip M. Dodol berenzim. Buletin Teknologi MARDI. 2012;2:113-7.

21. F. T. K. Ningrum, "Designing a booklet of a new variant of dodol from corn," 2017. [Online]. Available: http://eprints.polsri.ac.id/4261/3/FILE\%20III.pdf.

22. Tibbetts G. Pre-Islamic Arabia and South-East Asia. J Malayan Branch R Asiatic Soc. 1956;29(3):182-208

23. Othman M. Islam and Cultural Heritage From Trade Relations between The Middle East and The Malay World. Journal of Islam and Contemporary World. 2003;107-146. Retrieved from http://tafhim.ikim.gov.my/index.php/ta fhim/article/view/68

24. Hussein I. Pengajian Melayu di Malaysia - Menjelang Abad ke-21. In: Adat Pepatih Melayu-Champa. Kuala Lumpur: Kementerian Kebudayaandan Pelancongan Malaysia; 1994.

25. Omar R, Atoma P. Pluraliti Budaya dan Etnik di Alam Melayu Zaman Awal. In: Hubungan etnik di Malaysia: Perspektif teori dan praktik. Skudai: UTM Press: 2009 p. 55-70.

26. Wan Hashim WT. Dunia Melayu dan Tersebar Luasnya Rumpun Bahasa Melayu. In: Dunia Melayu. Kuala Lumpur: Dewan Bahasa dan Pustaka; 1991.

27. Abdul Rahman N, Kaw PNH. Tamadun Islam dan Asia. Kuala Lumpur: McGraw-Hill; 2008.

28. Marzali A. Peradaban Melayu-Nusantara. J Peradaban. 2017:5:23-48.

29. Helmi A. (2014). Peranan Perempuan dalam Home Industri Dodol Terhadap Kehidupan Ekonomi Sosial Rumah Tangga di Desa Paya Perupuk Kecamatan Tanjung Pura Kabupaten Langkat. Universitas Negeri Medan, Fakultas IImu Sosial. Sumatera Utara: Universitas Negeri Medan. 2014. Retrieved June 02, 2018, from http://digilib.unimed.ac.id/17958/.

30. Julya M, Sengim P. Dessert for Thai Festival. Bangkok: Universitas Negeri Medan; 2010. p. 155

31. Nasbah NN. Dodol Ideris 13 Perisa: Utusan Malaysia; 2009. [Online]. Available: http://ww1.utusan.com.my/utusan/info.asp?y=2009\&dt=122 9\&pub=Utusan_Malaysia\&sec=Selatan\&pg=ws_01.htm. Accessed 1 Apr 2018

32. Mohammad Zakaria N. Keunikkan Dodol Asiah: Utusan Malaysia; 2012. [Online]. Available: http://ww1.utusan.com.my/utusan/Selatan/20120828/ws_ 01/Keunikan-dodol-Asiah. Accessed 30 Mar 2018

33. Abdul Malek A. Dodol Bonda resepi asli: Sinar Harian; 2017. [Online]. Available: http://www.sinarharian.com.my/bisnes/dodol-bonda-resipi-asli-1. 656615. Accessed 09 June 2018

34. Zieman. Dodol: Sticky treat for Hari Raya; 2014

35. Ahmad R. Dodol daripada beras berwarna. Buletin Tek MARDI. 2012;2: 105-11.

36. R. Eckhardt, "Saveur," 2017. [Online]. Available: https://www.saveur.com/pa Im-sugar-malaysian-gula-melaka-recipes/. Accessed 28 Jan 2021. 
37. Md. Amin NA. Dodol upih di cari menjelang Syawal: Sinar Harian; 2021. [Online]. Available: https://www.sinarharian.com.my/article/138042/EDISI/ Dodol-upih-dicari-menjelang-Syawal. Accessed 09 June 2021

38. Ahmad F. Tidak menang tangan layan tempahan Dodol Malaya: Utusan Malaysia; 2021. [Online]. Available: https://www.utusan.com.my/berita/2 021/04/tidak-menang-tangan-layan-tempahan-dodol-malaya/. Accessed 09 June 2021

39. Abu Bakar A. Teknologi cetus dodol 13 perisa. Malacca: Media Mulia. 2011. Retrieved February 17, 2021, from http://akhbar-kosmo.blogspot.com/2011_ 09_11_archive.html.

40. Chuah TG, Hairul Nisah H, Thomas Choong SY, Chin NL, Nazimah SA. Effects of temperature on viscocity of dodol (concoction). J Food Eng. 2007;80(2): 423-30.

41. Nasaruddin F, Chin N, Yusof Y. Effect of processing on Instrumental textural properties of traditional dodol using back extrusion. Int J Food Properties. 2012;15(3):495-506.

42. Ibrahim F, Jamaluddin R. The Malay Traditional Leafen Art Food Packaging. The 5th Tourism Educators' Conference on Tourism and Hospitality. Penang: Universiti Sains Malaysia; 2007.

43. Hasballah. Mengenal Jenis-jenis Daun Pembungkusan Makanan; 2015.

44. Risch SJ. Food packaging history and innovations. J Agric Food Chem. 2009; 57:8089-92.

45. Tanhindarto RP. Mempertahankan Kombinasi Iridiasi dan Pengemas Modafikasi Atmosfer. In: Penelitian dan Pengembangan Aplikasi Isotop dan Iridiasi; 1998. p. 1-7.

46. Laistrooglai A, Mosikarat P, Wigran M. Packaging design with natural materials: a study for conservation. Nakhon Pathom: Silpakorn University Research \& Development Institute; 2000.

47. Guerrero L, Guardia M, Xicola J, Verbeke W, Vanhonacker F, ZakowskaBiemans $\mathrm{S}$, et al. Consumer-driven definition of traditional food products and innovation in traditional foods. A qualitative cross-cultural study. Appetite. 2009;52(2):345-54.

48. Mensah JK, Adei E, Adei I, Ashie MD. Perception of the use of indigeneous leaves as packaging materials in the ready-to-eat cornmeals. Int J Biol Chem Sci. 2012:6(3):1051-68

49. Sahari F, Hasan R, Durin A, Adruce SAZ, Rahman SA. Traditional food wrapping and packaging: culture and identity of the Saribas Malay, Sarawak. Int J Innovative Des Creativity Soc Sci. 2018;2(1):7.

50. Ismail NA, Mohd Ariffin NF. Longing for culture and nature: the Malay rural cultural landscape "Desa Tercinta". J Teknol. 2015;75(9).

51. Ismail NA, Utaberta N, Yazid M, Ismail S. A cultural responsive landscape study on Perak Malay garden: an expressional value. Adv Environ Biol. 2015; 9(5):485-90.

52. Malaysia T. Malaysia culinary delights. Kuala Lumpur: Tourism Malaysia, Ministry of Tourism and Culture, Malaysia; 2016.

53. Khadzir MK. Cara Buat Dodol Tradisional: Blogspot; 2012. [Online]. Available: http://denii-herdiansah.blogspot.my/2012/09/cara-membuat-dodol-tra disional.html. Accessed 17 Apr 2018

54. Mohd Zahari MS, Kamaruddin MS, Muhammad R, Kutut MZ. Modernization, Malay matrimonial foodways and the community social bonding. Int I Hum Soc Sci. 2011;5(8):1061-70.

\section{Publisher's Note}

Springer Nature remains neutral with regard to jurisdictional claims in published maps and institutional affiliations.

Ready to submit your research? Choose BMC and benefit from:

- fast, convenient online submission

- thorough peer review by experienced researchers in your field

- rapid publication on acceptance

- support for research data, including large and complex data types

- gold Open Access which fosters wider collaboration and increased citations

- maximum visibility for your research: over $100 \mathrm{M}$ website views per year

At BMC, research is always in progress.

Learn more biomedcentral.com/submissions 